\title{
Off-Line Tuning of Positioning Control System using Particle Swarm Optimization Considering Speed Controller
}

\author{
Takayuki Kaneko Member (Fuji Electric Advanced Technology Co., Ltd.) \\ Hiroyuki Matsumoto Member (Fuji Electric Advanced Technology Co., Ltd.) \\ Hironori Mine Member (Fuji Electric Advanced Technology Co., Ltd.) \\ Hideyuki Nishida Member (Fuji Electric Systems Co., Ltd.) \\ Tomoharu Nakayama Member (Fuji Electric FA Components \& Systems Co., Ltd.)
}

Keywords: motion control, positioning control, off-line tuning, system identification, Particle swarm optimization

This paper describes an optimal autonomous off-line tuning method for position controller in mechanical system using a new evolutionary algorithm called particle swarm optimization (PSO). The PSO technique is a method of obtaining the large region optimal solution, by having two or more searching points like GA. It is characterized by having the mechanism in which global search that maintains an old speed, and partial search are performed with sufficient balance.

Generally in the industry machinery, the autonomous performance to the position control system is getting more strongly demanded. In this paper, two approaches to the optimization are detailed. Fig. 1 shows the system flow of the proposed method.

First, frequency characteristics analysis is performed as nonparametric identification. From the analyzed frequency characteristics, the model structure and the parameters of a load machine are autonomously identified using PSO (Step 1). The model used for the system identification as a multi inertia load system that was composed of the groups of the factor module, and the evaluation function was error sum of squares with the frequency response.

Second, the parameters of a controller are autonomously tuned up using the identification result. In the case of the control structure that has a speed controller of a minor loop, in the positioning control, a speed controller suppresses disturbance at high speed. For the position controller, the performance of tracking reference is important. Therefore, it is thought necessary to optimize the performance by evaluating characteristics of tracking and disturbance rejection separately. In this paper, the parameters of a speed controller are optimized first and the position control system with the minor-loop of the speed controller is optimized using PSO (Step 2).

The effectiveness of the proposal method was confirmed by the experiment. Three inertia load system that requires a difficult adjustment of the control parameters was applied to the test plant system.
The proposal method was able to search for a good control coefficient to the system with two or more resonances, and confirmed to achieve a good performance when positioning was operated of the instruction that was the point-to-point profile.

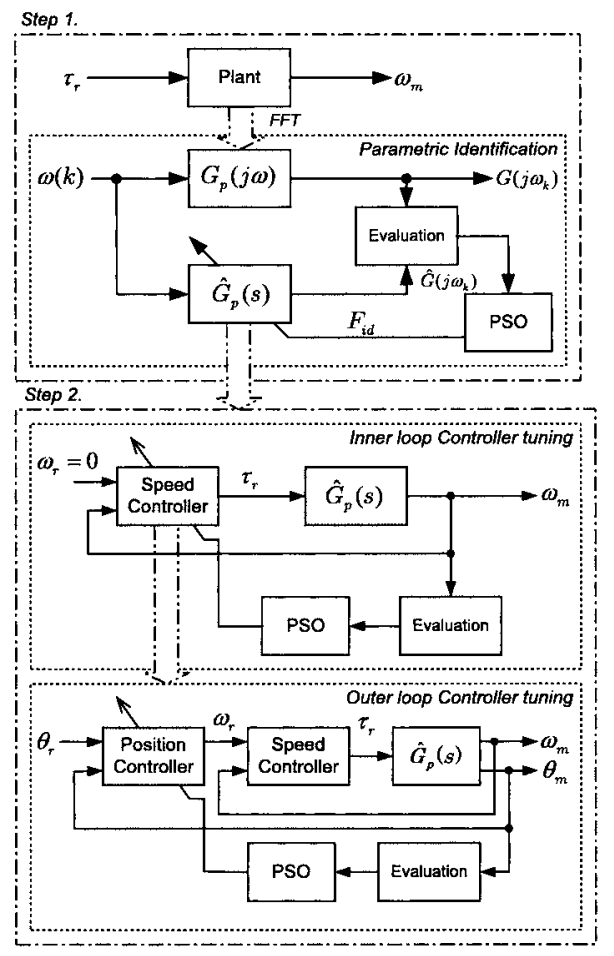

Fig. 1. System flow 


\section{位置決め制御系における速度制御マイナーループを考慮した Particle Swarm Optimization によるオフラインチューニング}

$\begin{array}{lllll}\text { 正員 } & \text { 金子 } & \text { 貴之* } & \text { 正 員 松本 } & \text { 寛之* } \\ \text { 正 員 美根 } & \text { 宏則* } & \text { 正 員 西田 } & \text { 英幸** } \\ \text { 正 員 中山 } & \text { 智晴*** } & & & \end{array}$

\section{Off-Line Tuning of Positioning Control System using Particle Swarm Optimization Considering Speed Controller}

Takayuki Kaneko*, Member, Hiroyuki Matsumoto*, Member, Hironori Mine*, Member, Hideyuki Nishida**, Member, Tomoharu Nakayama***, Member

This paper describes an optimal off-line tuning method for position controller in mechanical system using a new evolutionary algorithm called particle swarm optimization (PSO). Generally in the industry machinery, the autonomous performance to the position control system is getting more strongly demanded. In this paper, two approaches to the optimization are detailed. First, PSO is used in order to optimize the coefficient of a mathematical model as system identification. Second, the parameter of a controller will be directly optimized by evaluating a response using PSO. The proposed approach had superior features, including easy implementation, stable convergence characteristic, and good efficiency.

キーワード：モーションコントロール，位置決め制御，オフラインチューニング，システム同定， Particle Swarm Optimization

Keywords: motion control, positioning control, off-line tuning, system identification, Particle swarm optimization

\section{1. まえがき}

一般産業機械において，生産スピード(タクトタイム) が機械の性能指標であり，モーションコントロールとして の位置決め制御系，およびアクチュエータは重要な要素と なっている。一方，モーションコントロール側から見て，制 御対象となる機械系は多様化, 複雑化が進んでおり, 要求 仕様を満たすためには，より応答性，適応性の高さが求め られている。

この様な背景のなか, 小ロット, 短納期といった流れから 産業機械全体の設計開発プロセスを圧縮する動きが高まっ

\footnotetext{
*富士電機アドバンストテクノロジー（株）

于 191-8502 日野市富士町 1 番地

Fuji Electric Advanced Technology Co., Ltd.

1, Fuji-machi, Hino 191-8502

** 富士電機システムズ（株）

厂 191-8502 日野市富士町 1 番地

Fuji Electric Systems Co., Ltd.

1, Fuji-machi, Hino 191-8502

*** 富士電機機器制御（株）

干 513-8633 鈴鹿市南玉垣町 5520

Fuji Electric FA Components \& Systems Co., Ltd.

5520, Minamitamagaki-machi, Suzuka 513-8633
}

ており，専門的な知識を持たない人間でも，時間を掛ける ことなく数分で制御系の調整が可能となる様, 位置決め制 御としてのモーションコントロールには，より自律化され たシステム性能が要求されつつある(1)(2)。自律化されたシ ステムを構築するには, 制御対象となる機械系のモデル化 が必要であり, 特徴量としてのパラメータを得る場合, 負 荷機械に合わせた数学モデルを構築し, そのパラメータを 自律的に同定する必要がある。

また，制御系においては，一般産業機械へ適用する場合， 速度超過や現場での調整を考慮して, 速度制御によるマイ ナループを構成する場合がほとんどである。一重のループ による制御器の場合, 制御器の構造が固定され, 且つ制御 対象である機械系がモデル化されていれば，係数図法など の手法を用い, 最適なパラメー夕を求めることは出来るが, 速度制御系をマイナループに持つ多重ループ構造の場合, 制御帯域の制限によってマイナループを無視出来ない状況 が発生し, 制御器の構造が複雑となり一般の制御系設計手 法を適用することが困難となる場合が多い。

ところで, 文献 (1) (2) にて最適化手法として用いられて いる遺伝的アルゴリズム（以下：GA）は，連続值を扱う場 合，それぞれの変数值を表現する部分を適当な 2 進ビット 
列で表現する方法が基本的に用いられる事になる。これは， 沉用性や最適性を考えれば GA は離散構造の問題に適した 手法と考えるのが妥当である。

そこで筆者らは，近年注目され様々な適応例 ${ }^{(3) \sim(7)}$ が報告 されている最適化手法の 1 つである, Particle Swarm Optimization (以下:PSO) に着目した。PSO は連続变数の多峰 性関数の大域的最適解もしくは準最適解を求める事が可能 である。一般的に, 機械系のパラメータや制御器パラメー 夕は連続変数として考えることが出来るため, PSO は GA に対しアルゴリズムとしての収束性に優位であると考えら れる。本稿では，PSO を用いた速度マイナーループを含ん だ位置決め制御系における，システム同定も含めたオフラ インチューニング手法について検討し，実機を用いた検証 にて良好な結果を得たので報告する。

\section{2. オフラインチューニングの概要}

〈2・1〉チューニングの構造図 1 に本報告における 全体の流れを示す。まず，負荷機械系に対しノンパラメト リック同定として，モータへトルクを与え負荷である機械 系を加振し，PCなど外部の計算機にトルク，およびモータ 速度のデータを取り込み, FFTより周波数特性解析をおこ なう。

解析した周波数特性を用いて，外部の計算機により PSO

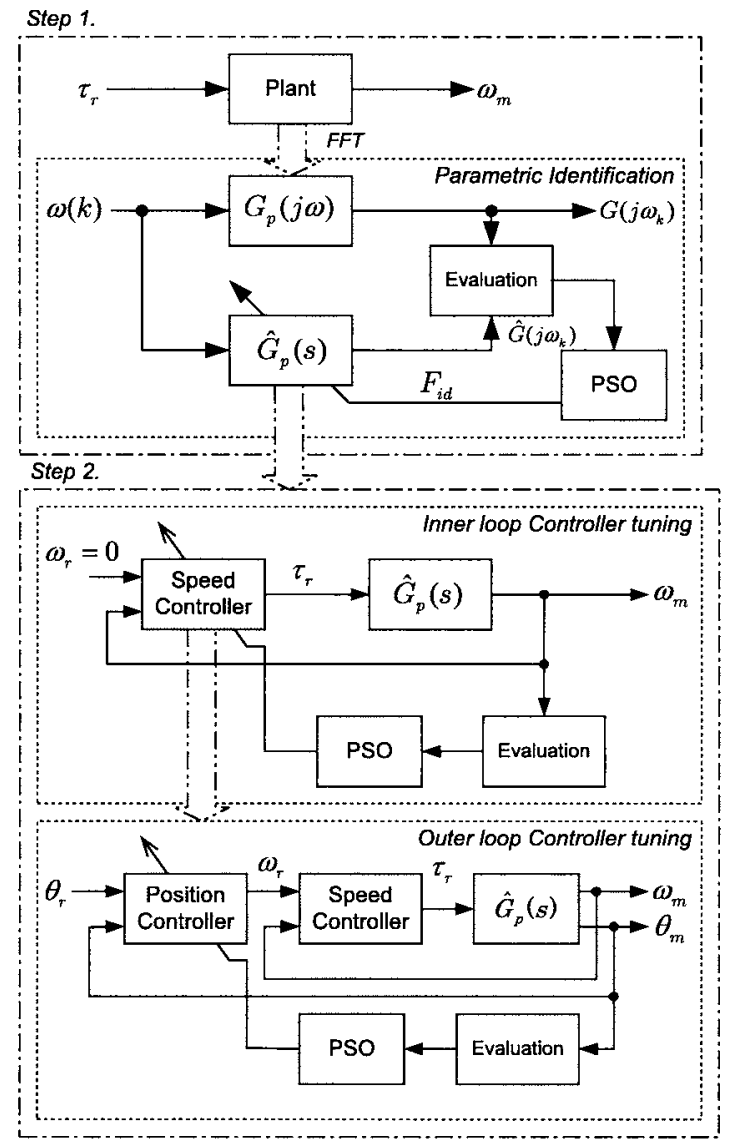

図 1 システムの流れ

Fig. 1. System flow.
を用いて負荷機械のモデル構造とパラメータを求める，パ ラメトリック同定をおこなう（Step 1)。次に，前記のパラ メトリック同定の結果を用い，計算機にて時間応答シミュ レーションし, 着目する制御応答を PSO にて最適化する事 により，仮想的に計算機内で制御器の制御定数をチューニ ングする。ここでは，速度制御系をマイナループに持つ制 御構造の場合, 通常のシステムでは, マイナループである 速度制御系が高速に応答して外乱を圧縮し, 外側の位置制 御系が目標值応答に対する追従性を重視した構成となる。 よって, 外乱抑圧応答および指令追従応答を別個に評価す ることにより最適化をおこなえば良い (Step 2)。

最終的には，計算機内で上記によって最適化された制御 定数を，実際の制御器に与えチューニングの完了となる。

$\langle\mathbf{2} \cdot 2\rangle \quad$ Particle Swarm Optimization ${ }^{(5)(8) \sim(10)} \quad$ PSO の概念図を図 2 に示す。PSO は多次元空間を数多くのエー ジェントが動き回り, 目的関数を最適化するアルゴリズム である。それぞれのエージェントは位置ベクトル $(s)$, 速度 ベクトル $(v)$ と，そのエージェントが最良の適合度を獲得 した場所 (pbest) を記憶する。そしてエージェント全体の 中における最良の適合值の情報 (gbest) もぞれぞれのエー ジェントが共有することが出来る。すべてのエージェント が多次元空間を動き回ることにより獲得した最も優れた位 置と, それぞれのエージェントが獲得した最も優れた位置 の方向へ，エージェントが引きよせられると理解し易い。 その方法は (1) 式および (2) 式によって実現される。

$$
\begin{aligned}
& v_{i}^{k+1}=\omega \cdot v_{i}^{k}+c_{1} \cdot \operatorname{rand}() \cdot\left(\text { pbest }_{i}-s_{i}^{k}\right) \\
& +c_{2} \cdot \operatorname{rand}() \cdot\left(\text { gbest }-s_{i}^{k}\right) \\
& s_{i}^{k+1}=s_{i}^{k}+v_{i}^{k+1}
\end{aligned}
$$

ここで

$s_{i}^{k}:$ エージェントの探索 $k$ 回時の位置

$v_{i}^{k}:$ エージェントの探索 $k$ 回時の速度

$\omega:$ エージェント速度に対する重み

$c_{1}, c_{2}:$ 各項に対する重み

$\operatorname{rand}(): 0 \sim 1$ までの乱数

pbest $t_{i}$ : エージェントのそれまでの最良位置

gbest：エージェント全体のそれまでの最良位置

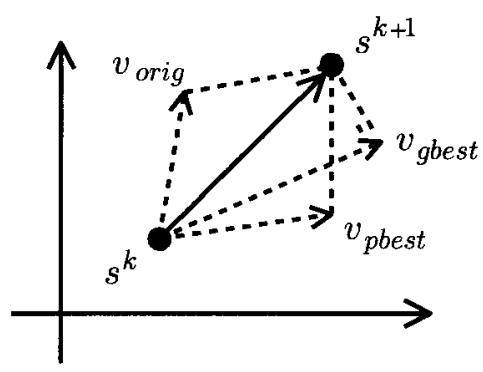

図 2 PSO の概念図

Fig. 2. Modification of a searching point. 
PSO は, GA などと同様に複数の探索点を持ち, 探索点の pbest と, 集団の gbest とを用いて各探索点を確率的に変更 していくことにより，大域最適解を得る方法であり，これ までの速度を維持する大域的探索（(1) 式右辺第 1 項）と， pbest および gbestを用いてそれに近づこうとする局所探 索（(1) 式右辺第 2，3 項）とをバランス良く行う機構を持 つことを特徴とする。

本論文では，(1)式の重みに関しては，文献 (5) (8) などで 推奨されている值を用いる。 $c_{1}, c_{2}$ に関しては $c_{1}=c_{2}=2.0$ とし， $\omega$ に関しては， $k_{\max }$ を最大探索回数として次式の関 数とする。

$$
\omega=\omega_{\max }-\frac{\omega_{\max }-\omega_{\min }}{k_{\max }} \cdot k
$$

(3) 式において, $\omega_{\max }, \omega_{\min }$ に関しても推奨值である $\omega_{\max }=0.9, \omega_{\min }=0.4$ を適用する。

\section{3. 未知構造のシステム同定}

〈3・1〉 モデルの構造 負荷機械特性をバネやバック ラッシ等の非線形な要素を排除した多慣性系としてモデリ ングすれば，多慣性系のトルクと速度の関係は図 3 で表す ことができる。ここで， $J_{1}$ はモー夕軸周りの慣性モーメン 卜， $\tau_{1}$ はモー夕が発生するトルク， $\omega_{1}$ はモー夕軸の速度で ある。多慣性系の場合それぞれの慣性 $J_{n}$ は，ねじりバネ要 素 $K_{k-1}$ 及びダンピング要素 $D_{k-1}$ で結合されていると考え られる。図 3 より $\omega_{1} / \tau_{1}$ は，次式で表すことができる。

$$
G_{p}(s)=\frac{\omega_{1}}{\tau_{1}}=\frac{1}{s J_{1}} \cdot \prod_{i=1}^{k-1} \frac{s^{2}+2 \zeta_{n i} \omega_{n i} s+\omega_{n i}^{2}}{s^{2}+2 \zeta_{d i} \omega_{d i} s+\omega_{d i}^{2}}
$$

ここで,

$$
\begin{aligned}
& \omega_{n i} \text { : 反共振角周波数 } \\
& \omega_{d i} \text { : 共振角周波数 } \\
& \zeta_{n i}, \zeta_{d i} \text { : 減衰定数 }
\end{aligned}
$$

多慣性負荷系の特徵はその極によって左右され，一般的 に $\zeta_{d i}$ は非常に小さい。従って，共振角周波数相当の振動 が生じる。ここで，各因子 $\left(\omega_{n i}, \zeta_{n i}\right.$ 又は $\left.\omega_{d i}, \zeta_{d i}\right)$ の集ま りをモジュールとして表現し，システムを因子モジュール の集まりにより構成されるものと考える。例えば，負荷が 1 慣性であれば，使用するパラメー夕は $J_{1}$ のみで構成され

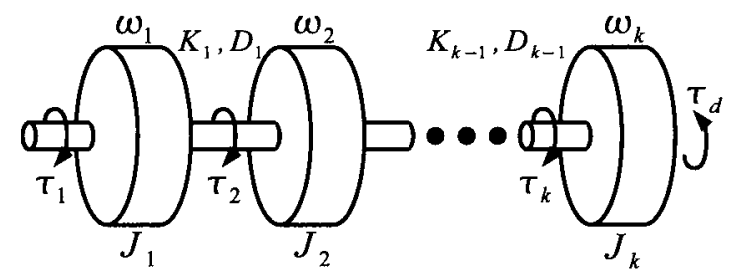

図 3 多慣性負荷のモデル

Fig. 3. Multi-Mass System.
る。また, 2 慣性の共振系ならば, $J_{1}$ のほかに分母・分子そ れぞれ一つずつのモジュールで構成される。3 慣性以上の 高次の構成でも, 複数のモジュールの集合として構成でき る。すなわち, $J_{1}$ の值とモジュールの数 $k-1$, 各モジュー ルに含まれる $\omega_{n i}, \zeta_{n i}$ と $\omega_{d i}, \omega_{d i}$ を決定することにより， 未知の多慣性負荷の特性を同定することができる。

$\langle\mathbf{3 \cdot 2}\rangle$ 同定と評価関数 次にPSO で用いる評価関数 を (5) 式に示す。サンプリング周期 $T_{s}$ で取得した $M$ 点の デー夕から求めた, 周波数 $\omega_{h}(h=0,1, \ldots, M / 2)$ における 実際の周波数応答 $G_{p}\left(e^{j \omega_{h} T_{s}}\right)$ と, 各エージェントから得ら れた周波数応答 $\hat{G}_{p}\left(e^{j \omega_{h} T_{s}}\right)$ の誤差積分 $F_{i d}$ をとる式となる。 $W_{i d}(h)$ は重み関数であり, 周波数軸に対する応答のデー夕 点に合わせたものとする。

$$
F_{i d}=\sum_{h=1}^{M / 2} W_{i d}(h)\left\{G_{p}\left(e^{j \omega_{h} T_{s}}\right)-\hat{G}_{p}\left(e^{j \omega_{h} T_{s}}\right)\right\}^{2} \ldots \ldots
$$

ここで, PSO での探索を効率よく行うために, (4) 式の $\omega_{d i}$, $\omega_{n i}$ に対し以下の制約条件を与える。

$$
\omega_{d i}>\omega_{n i}
$$

よって, パラメータ $K_{n i}$ を導入して PSO で探索する変数と し，次式で反共振周波数を求める。

$$
\omega_{n i}=K_{n i} \cdot \omega_{d i}\left(0<K_{n i}<1\right)
$$

\section{4. 制御系のチューニング}

〈4・1〉 外乱抑圧応答のチューニング＼cjkstart前節で同定し た制御対象のモデルを用い，外乱抑圧応答に対し制御定数 を最適化する。図 4 に, 最適化する速度制御系の構成図を 示す。速度制御器は PI 制御に，(8) 式に示すような 2 次の ノッチフィルタを直列に 2 段接続した構成とし, 複数の共 振に対しても安定した制御を実現しやすい構成とした。

$$
G_{n o t c h}(s)=\frac{s^{2}+2 \zeta_{n t} \omega_{n t} s+\omega_{n t}^{2}}{s^{2}+2 \zeta_{n t} s+\omega_{n t}^{2}}
$$

次に, 最適化時の評価方法について説明する。評価は外 乱に擬似的なインパルス信号 $\tau_{d i s}$ を注入し, その応答であ るモー夕速度の時系列データ $\omega_{m}(n)$ を用い外乱抑圧特性を 評価する。評価には，以下の 3 点に着目した。

(1) 振動に関する評価関数: $F_{s v i}$

(2) 安定性に関する評価関数: $F_{s d i}$

(3) 速応性に関する評価関数: $F_{\text {smo }}$

ここで，それぞれの個別の評価関数を以下に示す。

$$
\begin{aligned}
& F_{\text {svi }}=W_{\text {svi }} \sum_{n=1}^{N} g_{v}(n) \ldots \ldots \ldots \ldots \ldots \ldots \ldots \ldots \ldots \ldots \\
& F_{s d i}=W_{\text {sov }} \cdot \omega_{\text {max }}+\sum_{n=1}^{N}\left\{W_{s d i}(n) \cdot\left|\omega_{m}(n)\right|\right\}
\end{aligned}
$$

$$
F_{\text {smo }}=W_{\text {smo }} \frac{t(n)}{t(N)} \quad \text { if }\left\{\left|\omega_{m}(n)\right|<\omega_{\text {zero }}\right\}
$$




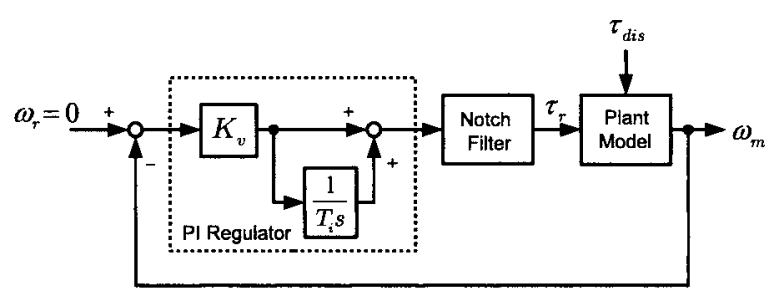

図 4 速度制御系のブロック図

Fig. 4. Block diagram of Speed Controller.

なお, $g_{v}(n)$ はモー夕速度 $\omega_{m}(n)$ の符号変化より, 振動の回 数を検出する関数で，次式に示す。

$$
g_{v}(n)=\left\{\begin{array}{l}
1: \operatorname{sign}\left\{\omega_{m}(n-1)\right\} \neq \operatorname{sign}\left\{\omega_{m}(n)\right\} \\
0: \operatorname{sign}\left\{\omega_{m}(n-1)\right\}=\operatorname{sign}\left\{\omega_{m}(n)\right\}
\end{array}\right.
$$

また, $W_{s d i}(n)$ は時系列の重み関数， $W_{s v i}, W_{s o v}, W_{s m o}$ は 重み係数， $\omega_{\text {zero }}$ はしきい值である。これら評価結果の総和 を，総合的な評価結果 $F_{d i s}$ とする。

$$
F_{d i s}=F_{s v i}+F_{s d i}+F_{s m o}
$$

最適化する制御定数は, PI 制御器の比例ゲイン $K_{v}$, 積 分時定数 $T_{i}$ および，ノッチフィルタの係数 $\zeta_{n t}$ となる。な お，PSOによる探索を効率化させるために，ノッチフィル 夕の周波数 $\omega_{n t}$ は，前節で同定した制御対象の共振周波数 $\omega_{d i}$ とする。

$\langle 4 \cdot 2\rangle$ 目標值応答のチューニング 図 5 に，本報告 における位置制御ループの構成を示す。時定数 $\tau_{p}$ の前置 フィルタ，および比例要素 $K_{p} に$ に, 微分要素を含んだフィー ドフォワード $K_{f}$ を加えた構成とする。次に, 最適化時の 評価方法について説明する。通常，一般産業機械における 位置決め制御は，図 6 に示すような Point To Point（PTP） の動作が一般的であり，指令值は，速度が台形となる指令 パターンを用いる場合がほとんどである。

そのため，位置指令が完了後における位置偏差 $e$, およ びトルク指令 $\tau_{r}$ などを評価するのが妥当と考えられる。以 上の条件を踏まえ，評価には以下の 3 点に着目した。

(1) 位置決め終了までの時間が短いこと。: $F_{p t s}$

(2) 位置偏差のオーバーシュートが小さいこと。: $F_{p e o}$

(3) トルクの残留振動が小さいこと。: $F_{p s v}$ 上記の着目点に基づいた評価関数を以下に示す。

$$
\begin{aligned}
& F_{p t s}=W_{p t s} \cdot t_{e}(n) \quad \text { if }\left\{|e(n)|<e_{z e r o}\right\} \cdots \cdots \cdots \\
& F_{p e o}=W_{p e o} \cdot|e(n)| \quad \text { if }\{|e(n)|>|e(n-1)|\} \\
& F_{p s v}=W_{p s v} \sum_{n=1}^{N} g_{t}(n) \ldots \ldots \ldots \ldots \ldots \ldots \ldots \ldots
\end{aligned}
$$

$t_{e}$ は，図 6 に示すとおり，位置指令完了後からの時間であ り, 関数 $g_{t}$ は, (12) 式と同様に, トルク指令 $\tau_{r}$ の符号変 化より振動の回数を検出する関数で，次式に示す。

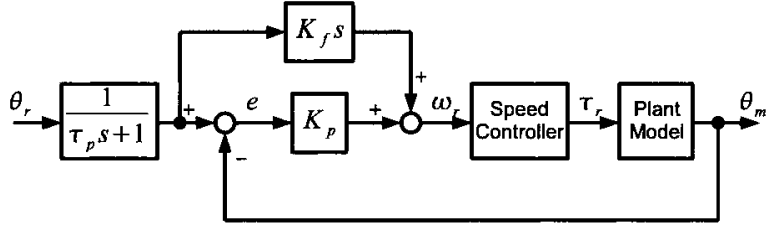

図 5 位置制御系のブロック図

Fig. 5. Block diagram of Position Controller.

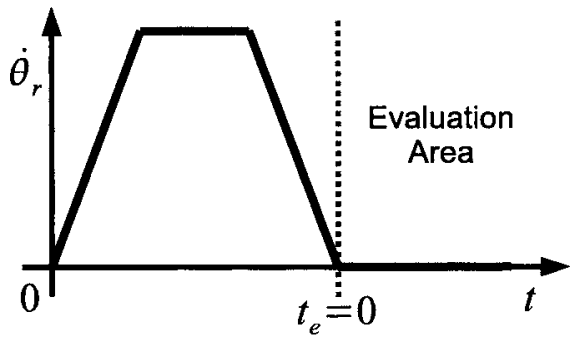

図 6 位置指令パターン

Fig. 6. Profile of Position command.

$$
g_{t}(n)=\left\{\begin{array}{l}
1: \operatorname{sign}\left\{\tau_{r}(n-1)\right\} \neq \operatorname{sign}\left\{\tau_{r}(n)\right\} \\
0: \operatorname{sign}\left\{\tau_{r}(n-1)\right\}=\operatorname{sign}\left\{\tau_{r}(n)\right\}
\end{array}\right.
$$

また， $e_{\text {zero }}$ は位置決め完了を判断する，偏差収束のしきい 值であり, $W_{p t s}, W_{p e o}, W_{p s v}$, は速度制御の評価と同様に 重み係数である。これら評価結果の総和を, 総合的な評価 結果 $F_{t r}$ とする。

$$
F_{t r}=F_{p t s}+F_{p e o}+F_{p s v}
$$

\section{5. 実験による検証}

〈5・1〉制御対象実機を用いた検証にて，本方式の 有効性を確認する。実機検証には，一般的に制御パラメー 夕の調整が困難と言われる，3慣性系の軸ねじれモデルを 対象とした。図 7 に対象モデルである実験装置の概観を示 す。実験装置は ACサーボモータで駆動され，モー夕に取 り付けられたエンコーダから得られた位置情報によりモー 夕の速度を測定する。ここで，機械定数及びモー夕の緒元 を表 1 に示す。

〈5・2〉 システム同定結果 まず，モー夕を加振させ 負荷機械系の周波数特性を取得する。ここでは, 擬似白色 信号である $\mathrm{M}$ 系列符号をトルク指令として与えて負荷機械 を加振し，モータの速度情報を計測する事により，周波数 特性を求める。ここで，M 系列符号のビット数は 10 [bit] (1024 点), 入出力データのサンプル周期は $T_{s}=250$ [ $\left.\mu \mathrm{sec}\right]$ とした。

図 8 に計測した入出力データ, 図 9 に入出力データより求 めた周波数特性を示す。図 9 より, $200[\mathrm{~Hz}]$ および $700[\mathrm{~Hz}]$ 付近に 3 慣性系の軸ねじれによる機械共振が確認できる。

次に，上記周波数特性用い, PSO を用いたパラメトリッ ク同定を実施する。表 2 に探索の条件を示す。 


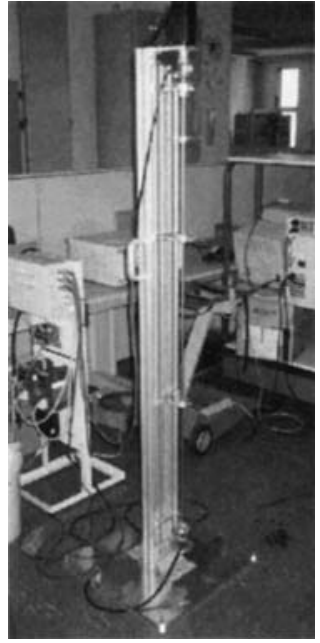

図 7 実験装置の外観

Fig. 7. Appearance of experimental system.

表 1 実験装置の緒元

Table 1. Specification of test equipment.

\begin{tabular}{l|l}
\hline \multicolumn{2}{c}{ Motor(AC Servo Motor) } \\
\hline Rated Power & $400[\mathrm{~W}]$ \\
\hline Rated Speed & $3000[\mathrm{r} / \mathrm{min}]$ \\
\hline Moment of inertia & $3.559 \times 10^{-5}\left[\mathrm{~kg} \cdot \mathrm{m}^{2}\right]$ \\
\hline Resolution of encoder & $65536 \mathrm{pulse} / \mathrm{rev}$ \\
\hline \hline \multicolumn{2}{|c}{$\mathrm{Load}$} \\
\hline Moment of inertia (1) & $13.2 \times 10^{-5} \mathrm{~kg} \cdot \mathrm{m}^{2}$ \\
\hline Moment of inertia (2) & $7.97 \times 10^{-5} \mathrm{~kg} \cdot \mathrm{m}^{2}$ \\
\hline Shaft material & $\begin{array}{l}\text { Stainless }(\mathrm{d}=8 \mathrm{~mm}) \\
\text { Modules of rigidity }(\mathrm{G}=80 \mathrm{GPa})\end{array}$ \\
\hline
\end{tabular}
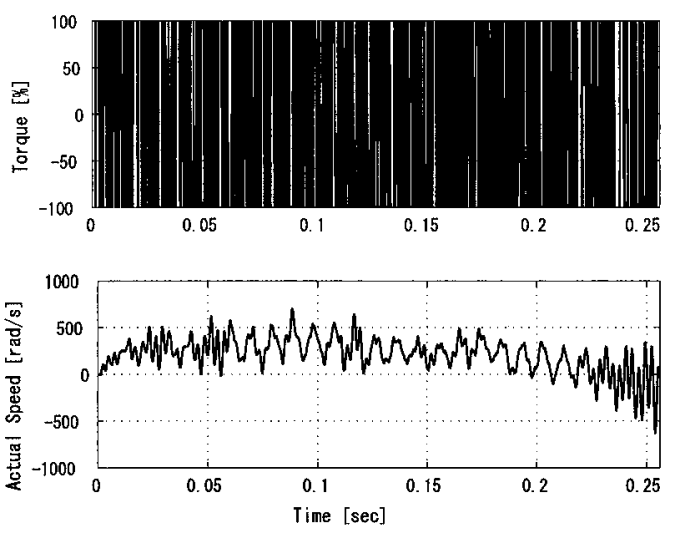

図 8 入出力デー夕

Fig. 8. Input/Output data for identification.

ここで，図 9 を見ると，高域の位相特性が著しく悪化し ている事が判る。これは, 変換器や検出系の遅れによる影 響であり，本論文では前記の遅れ分は既知として後述する 制御器のチューニングに組み込まれることになる。従って, 評価関数には周波数特性における位相特性は用いず，絶対 值の誤差を評価することとした。また，重み関数 $W_{i d}(h)$ は 低域における特性を重視する関数とし，実際には (5) 式を 次式に修正して扱う。
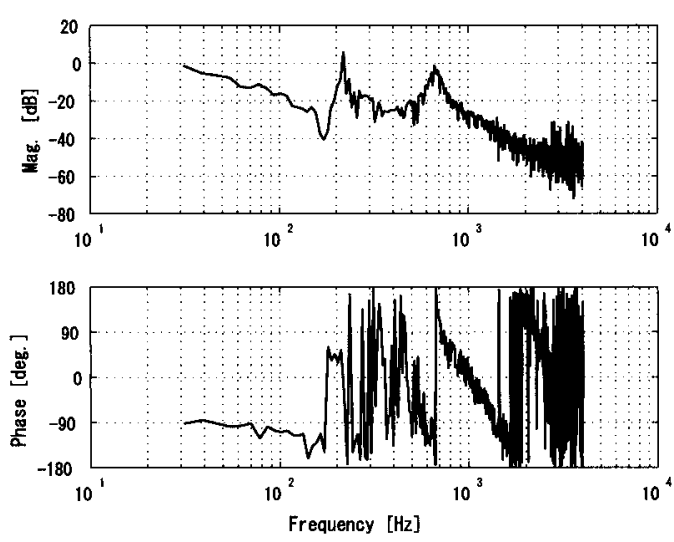

図 9 制御対象の周波数特性

Fig. 9. Frequency response of plant system.

表 2 システム同定の条件

Table 2. Parameters for system identification.

\begin{tabular}{l|l}
\hline Number of Agent & 200 \\
\hline Number of Iterations & 100 \\
\hline Search range of $k$ & $1 \sim 4$ \\
\hline Search range of $J_{1}$ & $0.216 \sim 21.60\left[\mathrm{kgcm}^{2}\right]$ \\
\hline Search range of $\omega_{d i}$ and $\omega_{n i}$ & $3 \mathrm{~Hz} \sim 3[\mathrm{kHz}]$ \\
\hline Search range of $\zeta_{s i}$ and $\zeta_{n i}$ & $0 \sim 0.2$ \\
\hline
\end{tabular}
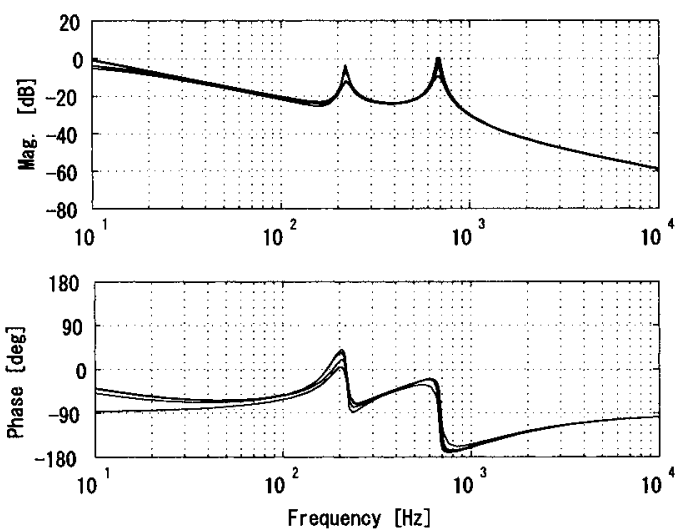

図 10 同定結果の周波数応答特性

Fig. 10. Frequency response of identified model.

$$
F_{i d}^{\prime}=\sum_{h=1}^{M / 2} \frac{1}{h}\left\{\left|G_{p}\left(e^{j \omega_{h} T_{s}}\right)\right|-\left|\hat{G}_{p}\left(e^{j \omega_{h} T_{s}}\right)\right|\right\}^{2}
$$

5 回同定した周波数応答を重社書きしたものを図 10 に， 繰り返し最適化における評価関数の出力を図 11 に示す。同 定した共振の数を表す, 組み合わせ数 $k$ は全て 3 となった。 また, 同定結果の平均值を表 3 に示す。提案法は, 速やか に真值の近くに同定出来ることを確認した。

〈5・3〉 チューニング結果＼cjkstart次に，システム同定した制 御対象の数值モデルを用い, 数值計算により求めた各時系 列デー夕を評価することにより各制御器の制御定数を PSO により自動調整する。評価に用いる時系列データの計算に は, 4 次の Runge-Kutta 法を用い, 刻み時間は $10[\mu \mathrm{sec}]$ と した。また，実際の機器を考慮し，時系列データの計算に 


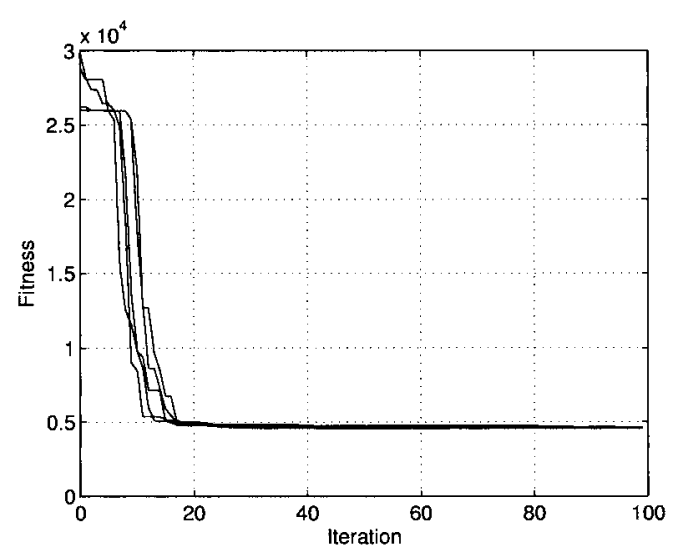

図 11 繰り返し数に対する適合度 (システム同定)

Fig. 11. Fitness of iteration (system identification).

表 3 同定結果

Table 3. Identified parameters.

\begin{tabular}{l|l}
\hline$J_{1}$ & $6.82 \times 10^{-5}\left[\mathrm{~kg} \cdot \mathrm{m}^{2}\right]$ \\
\hline$\omega_{d i}$ & $216.8[\mathrm{~Hz}], 676.8[\mathrm{~Hz}]$ \\
\hline$\omega_{n i}$ & $174.3[\mathrm{~Hz}], 672.4[\mathrm{~Hz}]$ \\
\hline$\zeta_{d i}$ & $0.005,0.008$ \\
\hline$\zeta_{n i}$ & $0.01,0.2$ \\
\hline
\end{tabular}

表 4 速度制御系のチューニング条件

Table 4. Tuning parameters for speed controller.

\begin{tabular}{l|l}
\hline Number of Agent & 1000 \\
\hline Number of Iterations & 20 \\
\hline Search range of $\omega_{s c}\left(=K_{v} / J_{a}\right)$ & $6 \sim 6000[\mathrm{rad} / \mathrm{s}]$ \\
\hline Search range of $T_{i}$ & $1.0 \sim 1000.0[\mathrm{~ms}]$ \\
\hline Search range of $\zeta_{n t}$ & $0 \sim 1.0$ \\
\hline
\end{tabular}

はモータを駆動する電力変換器相当のモデルや, 検出系と してのむだ時間を含んだ構成としている。まず，速度制御 系のチューニングをおこなう。関係する各条件（エージェ ント, 繰り返し数, 探索範囲) を表 4 に示す。比例ゲイン $K_{v}$ は，全機械系が剛体とした場合の総慣性を $J_{a}$ とし，速 度制御系のカットオフ周波数 $\omega_{s c}$ として次式より与える。

$$
\omega_{s c}=K_{v} / J_{a}
$$

なお，外乱の擬似インパルスは，制御出力の飽和を避 けるために，定格トルクに対し $15 \%$ の矩形波状のトルクを 1 [ms]の間与えた。また，(9)，(10)，(11) 式における評価 関数の重み係数およびしきい值はそれぞれ， $W_{v i b}=5.0$, $W_{o s}=0.001, W_{\text {mov }}=20, \omega_{\text {zero }}=0.1[\mathrm{r} / \mathrm{min}]$ とし，重み関 数である $W_{d i v}(n)$ は，過渡状態におけるモー夕速度が発振 状態に対するペナルティ関数とした。

チューニングの結果を表 5 に，調整された制御定数を用 いた外乱応答である，速度応答およびトルク応答を図 12 に, 繰り返し最適化における評価関数の出力を図 13 に示 す。提案する手法は，共振が複数ある負荷でも，制御定数 をPSOにより自動調整し，インパルス状の外乱に対して，
表 5 速度制御系のチューニング結果

Table 5. Adjusted parameters of speed controller.

\begin{tabular}{l|l}
\hline$\omega_{s c}\left(=K_{v} / J_{a}\right)$ & $660[\mathrm{rad} / \mathrm{s}]$ \\
\hline$T_{i}$ & $17.4[\mathrm{~ms}]$ \\
\hline$\zeta_{n t}$ & $0.1,0.6$ \\
\hline
\end{tabular}
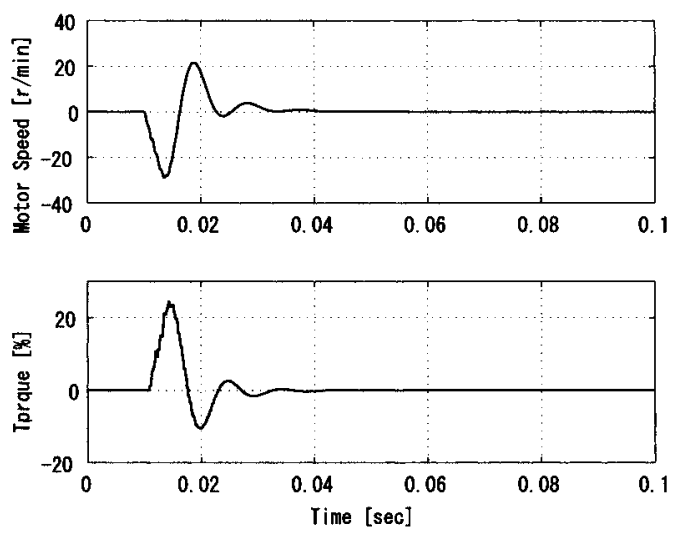

図 12 最適化された速度制御系の外乱応答 (数值計算)

Fig. 12. Disturbance responses using adjusted speed controller. (numerically calculated)

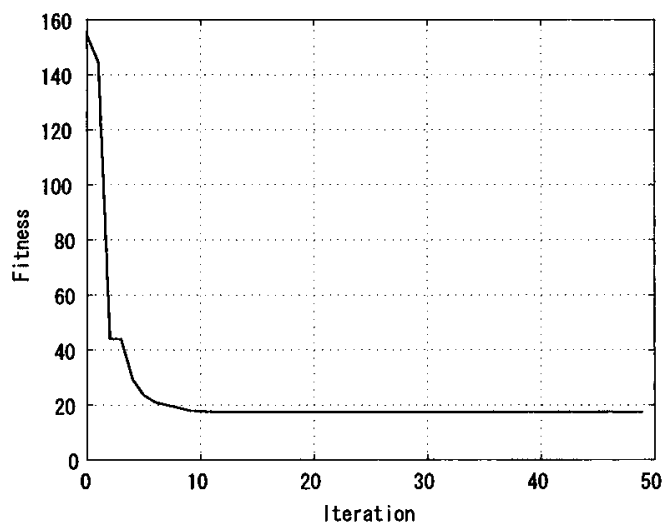

図 13 繰り返し数に対する適合度 （速度制御系のチューニング）

Fig. 13. Fitness of iteration (Tuning of speed control loop).

振動が収束する様に安定に動作することを確認した。

次に, 調整された速度ループを用い, アウターループであ る位置制御系をチューニングする。調整に関する条件を表 6 に示す。ここで, (14), (15) 式で用いた，しきい值および重み はそれぞれ, $e_{\text {zero }}=20$ [pulse], $W_{\text {pts }}=1000, W_{\text {peo }}=0.05$, $W_{p s v}=5.0$, とした。また位置指令のプロファイルは, 図 6 で示した台形の速度軌跡となるパターンとし, 最高速度を 100 [r/min], 停止状態から最高速度間の加減速時間は 20 [ms] とした。

チューニングされた結果を表 7 に, 数值計算にて求めら れた応答 (モー夕速度, トルク, 位置偏差) を図 14 に, 繰 り返し最適化における評価関数の出力を図 15 に示す。位置 指令の払い出しが完了後, 速やかに位置偏差が収束し, PTP 
表 6 位置制御系のチューニング条件

Table 6. Condition of positioning response tuning

\begin{tabular}{l|l}
\hline Number of Agent & 100 \\
\hline Number of Iterations & 50 \\
\hline Search range of $K_{p}$ & $1 \sim 1000[\mathrm{rad} / \mathrm{s}]$ \\
\hline Search range of $\tau_{p}$ & $0 \sim 100[\mathrm{~ms}]$ \\
\hline Search range of $K_{f}$ & $0 \sim 1.5$ \\
\hline
\end{tabular}

表 7 位置制御系のチューニング結果

Table 7. Adjusted parameters of position controller.

$$
\begin{array}{l|l}
\hline K_{p} & 48[\mathrm{rad} / \mathrm{s}] \\
\hline \tau_{p} & 6.0[\mathrm{~ms}] \\
\hline K_{f} & 0.3 \\
\hline
\end{array}
$$
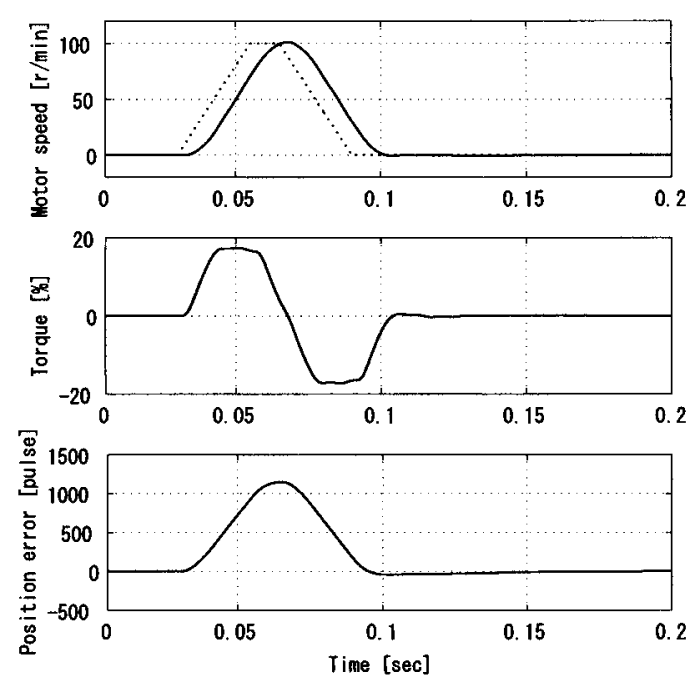

図 14 最適化された位置制御系の目標值応答 (数值計算)

Fig. 14. Tracking response using adjusted position controller. (numerically calculated)

動作として実用的な制御定数に調整されていることを確認 した。また，最適化されたパラメー夕を実機に適用して応 答を測定した結果を図 16 に示す。実際の応答波形は，若 干ながらの振動拉よびアンダーシュートが見られるが図 14 に示された数值計算で求めた応答に酷似しており, 本手法 の実用性が確認できた。

$\langle\mathbf{5} \cdot \mathbf{4}\rangle$ 処理時間に関する考察本論文の検証におい て最適化に要した計算時間は, Pentium M $1.6 \mathrm{GHz}$ の PC を用いた場合で，システム同定が約 50 秒，速度制御系の チューニングが約 2 分 45 秒，位置制御系のチューニング が約 45 秒であった。

提案する手法は, 最適化の処理に要する時間に関して, 繰 り返し数やエージェント数, 評価する外乱応答扔よび目標 值応答の長さに応じて変動する值となるが，本結果に打い て4 分弱で最適な制御パラメー夕を求める事が出来た事か ら，先に述べた，専門的な知識を持たない人間でも調整が 短時間で可能となるという点において実用性があると判断 できる。

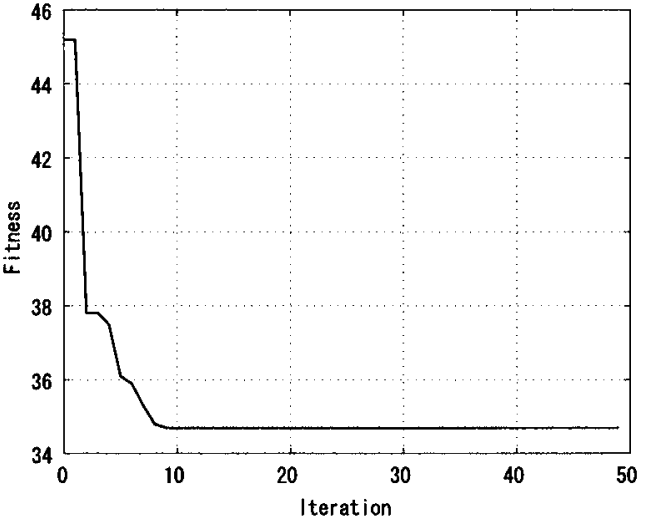

図 15 繰り返し数に対する適合度 (位置制御系のチューニング)

Fig. 15. Fitness of iteration (Tuning of position control loop).
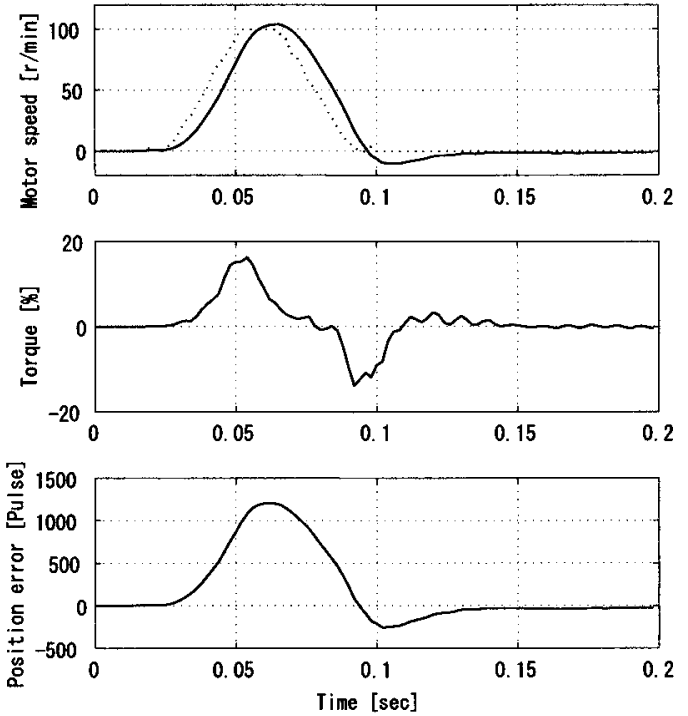

図 16 最適化された位置制御系の実験結果

Fig. 16. Experimental results using adjusted parameters.

\section{6. まとめ}

本論文では，マイナループに速度制御系を持つ位置決め 制御系に対して, PSO を用いて, 未知な構造の負荷に対し てシステム同定より数学モデルを構築し，時系列デー夕に よる評価から制御定数をオフラインチューニングする手法 を提案した。提案する手法は，共振が複数あるシステムに 対しても，最適な制御係数を探索することが可能であり，実 際の PTPによる位置決め動作において，良好な特性を確認 した。

なお本手法は，時系列デー夕を評価する点から，制御器 の飽和条件や，位置指令のプロファイルも含めた最適化シ ステムへの構築に発展が可能であると考えられる。これに ついては，検討を深め後に報告する予定である。

(平成 18 年 1 月 17 日受付, 平成 18 年 8 月 17 日再受付) 


\section{文献}

(1) K. Kristinsson and G.A. Dumont: "System Identification and Control Using Genetic Algorithms", IEEE Trans. on Sys. Man. Cybern., Vol.22, No.5, pp.1033-1046 (1992)

(2) M. Iwasaki, Y. Nagai, M. Kawafuku, H. Hirai, Y. Okubo, and T. Murakami: "GA-Based Practical Auto-Tuning for Fase and Precise Positioning Controller”, T. IEE Japan, Vol.125-D, No.6 pp.608-615 (2005-6) (in Japanese) 岩崎 誠·永井雄士 · 川福基裕・平井洋武·大久保弥市 - 村上哲雄 : 「GA による高速・高精度位置決め制御系のオートチューニング」, 電 学論 D, 125, 6, pp.608-615 (2005-6)

(3) H. Yoshida, K. Kawata, and Y. Fukuyama: "A particle swarm optimizationfor reactive power and voltage control considering voltage security assessment", IEEE Trans. Power Syst., Vol.15, pp.1232-1239 (2000)

(4) H. Yoshida, K. Kawata, Y. Fukuyama, S. Takayama, and Y. Nakanishi: "A Particle Swarm Optimization for Reactive Power and Voltage Control Considering Voltage Security Assessment", T. IEE Japan, Vol.119-B, No.12, pp.1462-1469 (1999-12) (in Japanese)

吉田裕宇 ·河田謙一・福山良和・高山信一・中西要祐：「電圧信頼度 を考慮した Particle Swarm Optimization による電圧無効電力制御方式 の検討」, 電学論 B, 119, 12, pp.1462-1469 (1999-12)

(5) K. Yasuda, A, Ide, and N. Iwasaki : "Particle Swarm Optimization: Dynamics Analysis and Its Application to Global Optimization", Prc. of Electronics, Information and System Conference Electronics, Infomation and Systems Society, IEE Japan, OS7-6 (2003) (in Japanese)

安田恵一郎・井出 東・岩崎信弘：「Particle Swarm Optimization：夕゙ イナミクスの解析と大域的最適化への応用」, 電気学会 $\mathrm{C}$ 部門大会 シンポジウム, No.OS7-6 (2003)

(6) Z.-L. Gaing: "A particle swarm optimization approach for optimum design of PID controller in AVR system", IEEE Trans. on Energy Conversion, Vol.19, No.2, pp.384-391 (2004)

( 7 ) Y. Matsui: "Design of Velocity Controller for 3-Mass System Using PSO", 2005 National Convention Record, IEE Japan, 4-201, pp.323-324 (2005) (in Japanese)

松井義弘：「PSO を用いた 3 慣性系のための速度制御器の設計」, 平 17 電学全大, 4-201, pp.323-324 (2005)

(8) J. Kennedy and R. Eberhart: "Particle swarm optimization", Proc. of IEEE Int. Conf. on Neural Networks, pp.1942-1948 (1995)

(9) R.C. Eberhart and Y. Shi: "Comparison between genetic algorithms and particle swarm optimization”, Proc. IEEE Int. Conf. Evol. Comput., pp.611-616 (1998)

(10) P.J. Angeline: "Using selection to improve particle swarm optimization", Proc. IEEE Int. Conf. Evol. Comput., pp.84-89 (1998)

(11) T. Kaneko, T. Aihara, and H. Mine: "System identification using Genetic Algorithm from Frequency Response data”, 2005 National Convention Record, IEE Japan, 4-234, p.381 (2003) (in Japanese)

金子貴之・藍原隆司・美根宏則：「周波数特性を入力とした GA に よるシステム同定の検討」, 平 15 電学全大, 4-234, p.381 (2003)

(12) M. Miwa, M. Iwasaki, H. Hirai, and N. Matsui: "Identification of Unknown Structured Motion Control System Using Genetic Algorithms”, $2000 \mathrm{Na}$ tional Convention Record, IEE Japan, No.4-219 (2000) (in Japanese) 三輪昌伸・岩崎 誠・平井洋武・松井信行：「遺伝的アルゴリズムに よる未知構造運動制御系の同定」, 平 12 電学全大, 4-219 (2000)

\section{金子貴 之}

(正員) 1999 年 3 月長岡技術科学大学大学院工 学研究科修士課程電気電子システム工学専攻修了。 同年 4 月富士電機 (株) に入社。現在, 富士電機ア ドバンストテクノロジー (株) エレクトロニクス 技術研究所。主として駆動制御を中心としたモー ション制御に関する研究に従事。

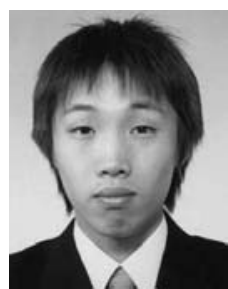

（正員） 2004 年 3 月長岡技術科学大学大学院工 学研究科修士課程電気電子システム工学専攻修 了。同年 4 月富士電機アドバンストテクノロジー （株）に入社。現在，エレクトロニクス技術研究 所。主として駆動制御技術を中心とした研究と開 発に従事。

美 根 宏 則 （正員） 1979 年 3 月東京大学工学部電子工学科

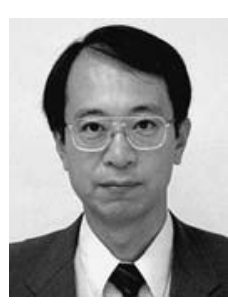
卒業。同年 4 月富士電機（株）に入社。現在, 富 士電機アドバンストテクノロジー（株）エレクト ロニクス技術研究所グループマネージャー。情報 処理機器, 電子応用機器, サーボシステム制御技 術の開発と研究に従事。電子情報通信学会，情報 処理学会会員。

西 田 英 幸

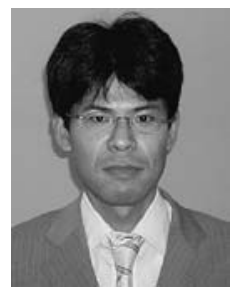

中 山 智 晴

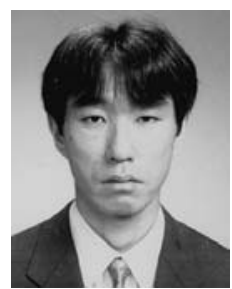

（正員） 1993 年 3 月大阪大学大学院基礎工学研 究科物理系専攻電気工学分野修了。同年 4 月富 士電機 (株) に入社。現在, 富士電機システムズ （株）産業プラント本部技術センターグループマ ネージャー。主として産業・船舶用電動力応用シ ステムの企画・設計に従事。

（正員） 1990 年 3 月北海道大学工学部電気工学 科卒業。同年 4 月富士電機（株）に入社。現在， 富士電機機器制御（株）インバー夕開発生産セン ター設計部。主としてモータドライブの研究開発 に従事。 